EESTI NSV TEADUSTE AKADEEMIA TOIMETISED 1955. IV kd., nr. 4 ИЗВЕСТИЯ АКАДЕМИИ НАУК ЭСТОНСКОИ ССР 1955. Том IV, № 4

\title{
EESTI BOLŠEVIKUD ESIMESE MAAILMASÕJA EEL
}

\author{
S. A. ZABRODSKAJA,
}

ajalooteaduste kandidaat

Viimased aastad enne Esimest maailmasõda olid võimsa revolutsioonilise tõusu ajaks Venemaal. Maa läks vastu uuele revolutsioonile.

Revolutsiooniline tõus toimus kogu riiki hõlmanud tööstusliku tõusu olukorras. Eestimaa kubermangus kasvas tööstuse toodang aastail $1910-$ 1913 enam kui 34 protsendi võrra ${ }^{1}$. Eriti kasvas metalli-, puidu- ja keemiatööstus ning ehitusmaterjalide tootmine. Tallinn muutus tähtsaks metallitööstuse, masina- ja laevaehituse suurtööstuslikuks keskuseks. Aastail 1912-1914 ehitati Tallinna kolm suurt laevaehitustehast ja Peeter Suure nimeline merekindlus, millega seoses tööliste arv järsult tõusis.

Tootmise kontsentreerumine ja monopolide mõju tugevnes. Suurettevõtete arv, kus töötas üle 500 töölise, tõusis Eestis XX sajandi algusest kuni 1913. aastani üheksalt seitsmeteistkümneni, töötajate arv nendes ettevõtetes suurenes aga 15650 fööliselt 31600 tööliseni ${ }^{2}$. Toimus ka pangakapitali ühtesulamine tööstuskapitaliga. 1913. aastaks tõusis Eestis tegutsevate tööstusettevõtete aktsiakapital ligi 100 miljoni rublani, kasvades kümne aastaga kolmekordseks ${ }^{3}$.

Eesti suurtööstus oli vene ja välismaise kapitali käes. Nii ehitas VeneBalti laevaehitustehast üks Venemaa suurimaid finantskapitali rühmitusi Vene-Aasia pank, mis oli loodud peamiselt prantsuse kapitaliga, Bekkeri tehaseid kontrollis Peterburi Kommertspank, kuna Noblessneri tehased kuulusid samanimelisele ühingule, mis oli seotud Nobeli ja Lessneri sõjatehastega Peterburis. Nendes finantsrühmitustes etendas tähtsat osa saksa kapital ${ }^{4}$.

Esimese maailmasõja eelõhtul moodustas välismaine kapital peaaegu poole kogu Eesti aktsiakapitalist ${ }^{5}$. Selleks ajaks olid kõik Tallinna, Narva, ja Pärnu tähtsamad ettevõtted allutatud vene ja välismaise kapitali monopolistlikele koondistele. .

Samal ajal kasvas majanduses ka eesti kodanluse osatähtsus. Eesti

1 Обзор Эстляндской губернии (Приложение к всеподданнейшему отчету) за 1910 г., стр. 25 и за 1913 г., стр. 25.

2 O. K a r ma, Jooni suurtööstuse arenemisest Eestis monopolistliku kapitalismi ajajärgul (kuni kapitalismi üldkriisi tekkimiseni). Eesti NSV Teaduste Akadeemia Toimetised 1952. I kd., nr. 4, lk. 35 .

3 Sealsamas, lk. 32 .

4 П. Л ящ ен ко, История народного хозяйства СССР. т. ІІ, стр. 583-584.

5 O. K a r m a, op. cit. lk. 32. 
kodanlus hakkas rajama suuremaid tööstusettevõtteid, nagu seda olid Viljandi ja Pärnu linavabrikud, mööblivabrikud jt. Selle tulemusena olid eesti kodanluse huvid veelgi tihedamalt seotud vene imperialismi huyidega.

Majandusliku tõusu aastail jätkus töölisklassi ekspluateerimise tugevnemine Venemaal, sealhulgas ka Eestis. Toimus töölisklassi absoluutne ja suhteline vaesumine.

Visa võitluse tulemusena saavutasid metalli-, puidu- ja paberitööstuse ning mõnede teiste tööstusharude töölised Eestis nominaalpalga väikese tõstmise, kuid samal ajal kasvas elukallidus ${ }^{6}$.

Töölisklass kannatas pika tööpäeva, ületunnitööde, madala töötasu, trahvide, töökaitse puudumise ning ebasanitaarsete töötingimuste ja administratsiooni jōhkruse ning omavoli all. Kapitalistlikule ekspluateerimisele lisandusid Eestis rahvuslik rõhumine saksa mõisnike ja kapitalistide ning vene kodanluse poolt, samuti ka tsaaripolitsei omavoli.

Töölisklassi suurenemine ja tema kontsentreerumine suurettevõtetes muutis töölisklassi - bolševike revolutsioonilise partei olemasolu tōttu - suureks revolutsiooniliseks jõuks.

Rikastatud 1905. a. revolutsiooni kogemustega ning vastu pidanud reaktsiooniperioodi rasketele katsumustele, aktiviseerus töölisklass 1910 . aastast alates, 1912. aastast alates aga asus uuesti otsustavalt võitlema tsarismi, mõisnike ja kapitalistide vastu.

Vahetu tõuke massilise revolutsioonilise liikumise otsustavaks tõusuks andis 4. aprillil 1912. aastal toimunud Leena veresaun. Selle vastu korraldatud protestistreigid langesid ühte 1912, a. maistreikidega, mis toimusid bolševike revolutsiooniliste loosungite all ning haarasid ligemale 400000 Venemaa töölist.

Artiklis „Revolutsiooniline tõus” kirjutas V. I. Lenin: „Kogu Venemaa proletariaadi suurejooneline maistreik ja sellega seotud tänavmeeleavaldused, revolutsioonilised proklamatsioonid ja töölishulkade ees peetud revolutsioonilised kõned näitasid selgesti, et Venemaa on jõudnud revolutsioonilise tõusu ajajärku ... kõik vene elu tingimused valmistasid seda ammugi ette ning massilised streigid, mis toimusid seoses Leena veresaunaga ja 1. mai puhul, määrasid vaid lõplikult kindlaks tõusu saabumise" 7 .

Eesti töölised vôtsid aktiivselt osa massilisest revolutsioonilisest liikumisest aastail 1912-1914. Sellest kõnelevad isegi ametliku statistika kaugeltki mitte täielikud andmed, mille kohaselt Eestimaa kubermangus toimus vabrikuinspektsioonile alluvais ettevōtetes 1911. aastal 5 streiki 352 töölise osavõtul. 1912. aastal aga toimus juba 44 streiki, millest võttis osa 14132 inimest, s. o. streikijate arv suurenes enam kui 40-kordseks. 1913. aastal kasvas streikijate arv 22109 inimeseni, 1914. aasta esimesel poolel (kuni sõja alguseni) aga 27725 inimeseni ${ }^{8}$.

Kogu Eestis, kui arvesse võtta Liivimaa kubermangu põhjaosa ning ettevõtted, mis ei kuulunud vabrikuinspektsiooni alla, võttis streikidest ametliku statistika, arhiivimaterjalide ning töölis- ja kodanlike ajalehtede andmete alusel tehtud arvutuste kohaselt osa: 1913. aastal vähemalt 28500 inimest, 1914. a. esimesel poolel aga 30000 inimest.

Streigiliikumise kasv Eestis ning selle liikumise seos üldise revolutsioonilise tõusuga pärast Leena veresauna olid sedavõrd ilmsed, et Eestimaa kubermangu sandarmivalitsus tegi 1912. aastal politseidepartemangule järgmise ettekande: „On tugevnenud agitatsioon streigiliikumise ning side-

6 Своды отчетов фабричных инспекторов за 1910-1913 гг.

7 V. I. L e n i n, Teosed, 18. kd., Ik. 83.

8 Andmed on võetud väljaandest Своды отчетов фабричных инспекторов за годы $1911-1914$. 
mete eest ülevenemaalise töölisliikumisega, ära kasutades Leena sündmusi ja 1. mai pühitsemist 9".

Aastail 1912 - 1914 toimus Tallinnas suuri poliitilisi väljaastumisi protestiks Leena veresauna vastu -- 1. mai puhul, 9. jaanuari ja 16 . oktoobri aastapäeva tähistamiseks jt.

Poliitiliste streikidega kaasnesid real juhtumeil demonstratsioonid, ning nad taotlesid mitte üksikuid, vaid üldrahvalikke eesmärke. Samal ajal hakkasid töölised üha aktiivsemalt osa võtma majanduslikest streikidest.

Majandušliku ja poliitilise võitluse läbipõimumine aga andis massilistele streikidele eriti suure revolutsioonilise jōu. Venemaa tööliste massilistel streikidel oli üldrahvalik tähtsus. Need olid suunatud isevalitsuse vastu. Nad äratasid ja tõmbasid võitlusse ka talurahva hulki ning avaldasid revolutsioniseerivat môju sõjaväele ja laevastikule.

Eestis toimub tõusuaastail klassivastuolude edasine teravnemine maal. Kõige revolutsioonilisemaks elemendiks, kes seisis tööstustöölistele kõige lähemal, olid põllutöölised, keda metsikult ekspluateerisid nii saksa parunid kui ka eesti kulakud. Sulaste tööpäev oli tohutult pikk, küündides suvel $18-20$ tunnini $^{10}$. Sulaste palk oli suurema osa tööstustööliste palgast veelgi madalam. Ulejōu käiva töö eest sai meessulane 100-150 rubla, naispõllutööline aga kõigest $60-80$ rubla aastas ${ }^{11}$.

Lisaks sellele polnud sulastel mingeid õigusi, nad kannatasid peremeeste meelevalla all ning elasid halbades elamutes.

Parem polnud ka popside ja väikerentnike olukord. Väikemaapidajad võisid vaid suure viletsusega võideldes ja kogu perekonna raske tööga säilitada oma majapidamist. Uha suurem arv nendest laostus.

Mõisnike rõhumisele vastasid sulased, popsid ja rentnikud stiihiliste väljaastumiste ja streikidega ning parunite hoonete ja varanduse põletamisega.

Ka sõjaväes algasid revolutsioonilised väljaastumised. Eestile oli eriti tähtis Balti laevastikus bolševike partei loosungite all arenev revolutsiooniline võitlus. Balti laevastiku bolševistlike organisatsioonide eesotsas seisis 1912. a. aprillist alates VSDTP Sõjalis-Revolutsiooniline Komitee, asukohaga Helsingis.

Balti laevastiku bolševikud olid partei Praha konverentsi otsustest informeeritud ja alustasid ettevalmistusi ülestõusuks, mis oli mõeldud osana üldrahvalikust väljaastumisest tsarismi vastu. Loodi side Musta mere laevastiku bolševikega.

Hoolimata sellest, et ohrankal ōnnestus juhtide massilise arreteerimise abil ära hoida ülestõusu katse 1912. a. aprillis, jätkus ülestõusu ettevalmistamine. 10. juunil 1912. aastal toimus Tallinnas Kadriorus kokkutulek, millest võttis osa umbes 100 revolutsioonilist madrust liinilaevadelt "Pavel I", „Tsessarevitš” ja ,Slava” ning ristlejalt „Rjurik”. Kokkutulekul arutati uue ülestõusu ettevalmistamise küsimust ${ }^{12}$.

Juuli algul saabus Narva-Jõesuusse (tolleaegne Hungerburg) liinilaevade brigaad. Selle koosseisus olid „Pavel I”,, „Tsessarevitš” jt.; brigaadis toimus aktiivne revolutsiooniline töö. 8. juulil kutsusid ettevalmistamisel oleva ülestõusu juhid Narva-Jõesuu metsas kokku suure miitingu ning määrasid ülestõusu ööle vastu 11. juulit. Olestõus ei toimunud, sest provokaatorite ettekannete põhjal arreteeriti ülestõusu juhid.

9 Riiklik Ajaloo Keskarhiiv Moskvas, Politseidepartemangu fond (f. 102), 4. osakond, aasta 1912 , säilitusühik 88,7 . osa, leht 3 .

10 «Правда» № 4 от 26 апреля 1912 г.

11 „Töö Hääl” nr. 13, 30. jaan. 1914.

12 Mere-Sōjalaevastiku Riiklik Keskarhiiv, f. 30, sü. 20. 
Revolutsiooniline võitlus laevastikus ei vaibunud aga ka hiljem, hoolimata julmast terrorist ${ }^{13}$. Revolutsioonilise võitluse 52 väljapaistvat osavôtjat laevastikus anti kohtu alla. 1913. aasta juunis toimunud kohtuprotsess kutsus esile Venemaa tööliste ulatusliku protestilaine, mille üheks avalduseks oli massistreik Tallinnas ${ }^{14}$. Tsaarivalitsus oli sunnitud kohtuotsust leevendama.

Revolutsioonilise liikumise kasv Venemaal jätkus. Klassivõitluse käigus läbiproovitud ja karastatud kommunistlik partei - uut tüüpi partei, kes on relvastatud revolutsioonilise teooriaga ja leppimatu oportunistide suhtes, leninismi partei - juhtis Venemaa töölisklassi uue revolutsiooni ettevalmistamisel.

1912. aasta jaanuaris toimunud partei Praha konverents viis bolševike faktilise lahkulöömise menševikest vormilise organisatsioonilise lahkulöömiseni, puhastas proletariaadi partei oportunistidest ning kihutas menševikud-likvidaatorid parteist välja. Praha konverents pani aluse bolševike formeerumisele omaette parteiks - Venemaa Sotsiaaldemokraatlikuks Tööliste (bolševike) Parteiks (VSDT (b) P).

Praha konverents märkis ära töölisliikumise uue tõusu tunnuseid ning seadis partei peamisteks järjekordseteks poliitilisteks loosungiteks võitluse demokraatliku vabariigi, 8-tunnise tööpäeva ja kõigi mõisamaade konfiskeerimise eest.

Praha konverentsi otsuste põhjal pidas partei võitlust illegaalsete parteiorganisatsioonide uuestiloomiseks, tugevdamiseks ja koondamiseks ning nende sidemete tihendamiseks massidega legaalsete võimaluste ärakasutamise teel.

Eestis olid parteiorganisatsioonid reaktsiooniaastatel tunduvalt nõrgenenud. Tõusuperioodi alguseks oli VSDT (b) P väljakujunenud organisatsioon säilinud ainult Tallinnas, kus oli olemas Tallinna komitee. Kahe aasta jooksul kujunesid välja ja kasvasid parteiorganisatsioonid ka Narvas, Tartus, Pärnus ja mujal. Eesti bolševike organisatsiooni tööst võtsid aktiivselt osa ka Peterburi ja Helsingi eesti bolševistlikud rühmad. Peterburi eesti bolševike organisatsiooni eesotsas oli Viktor Kingissepp. Kogu parteitööd kohapeal teostasid bolševikud - vabrikute ja tehaste töölised. Nad juhtisid streike, andsid välja ning levitasid lendlehti ja töötasid legaalseis töölisorganisatsioonides.

Parteiorganisatsioonide kujunemine, tugevnemine ja bolševiseerumine toimus 1912. a. keskpaigast alates bolševistliku „Pravda” ja eesti töölislehe „Kiir” ümber, mis sai „Pravda” ideede levitajaks Eestis.

Meie partei legaalne ajaleht „Pravda” võitles parteilisuse, massilise revolutsioonilise töölispartei taasloomise eest. Ta koondas legaalsed töölisorganisatsioonid põrandaaluste bolševistlike organisatsioonide ümber, propageeris marksismi-leninismi ideid ning tegi laialdast poliitilist agitatsioonilist ja määratu suurt organisatoorset tööd. „Pravda” abil kasvatas partei üles revolutsiooniliste tööliste-pravdistide uue põlvkonna, kes Suure Sotsialistliku Oktoobrirevolutsiooni päevadel moodustas partei põhituuma. Eesti eesrindlikud töölised lugesid ja levitasid „Pravdat”. 1913. aastal oli Eestis umbes 100 „Pravda” tellijat ${ }^{15}$. Peale selle osteti lehte veel üksikmüügilt. Likvidaatorliku ajalehe „Lutš” levik tööliste keskel oli tühine. Nii oli 1913. aasta märtsis „Lutši” tellijaid Eestimaa kubermangus ainult 12 inimest ${ }^{16}$.

13 Andmeid revolutsioonilisest liikumisest laevastikus vt. С. Ф. Н а й д а, Революционное движение в царском флоте, Изд. АН СССР, 1948 г., стр. 443-464.

14 «росвещение» № 6, 1913 г., стр. 84 .

15 „Töö Hääl” nr. 6, 14. jaan. 1914. a.

16 "Северная Рабочая Газета» № 51 и 52 от 11 и 12 августа 1914 г. 
Eesti töölised teostasid „Pravda” heaks korjandusi ning saatsid talle kirju ja kaastööd. „Dvigateli” tehases moodustas rühm teadlikke töölisi toimetuskomisjoni, kes kogus materjale ja saatis „Pravdale” kaastööd ${ }^{17}$. „Pravda” kirjutas tööliste olukorrast Eesti ettevõtetes, tööliste võitlusest, sulaste ja maakehvikute rasketest elutingimustest ning mõisnike, kulakute, kapitalistide ja tsaariadministratsiooni omavolist. Ta valgustas kõiki küsimusi elu ja klassivõitluse kohta Eestis. Veidi enam kui kahe aasta jooksul avaldati "Pravdas” ligemale 200 artiklit ja sõnumit Eestist. Omistades suurt tähtsust partei elu ja klassivõitluse küsimuste valgustamisele Baltikumis, laskis „Pravda” VSDT(b)P Keskkomitee korraldusel-18 välja lisalehe „Прибалтийский край” 19 (pühendatud peamiselt Lätile), milles valgustati ka olukorda Eestis. Selles ajalehe numbris avaldati ka tähtsaid parteidokumente Eestist, sealhulgas Eesti parteinõupidamise resolutsioon, mis tervitas duuma bolševistlikku fraktsiooni ${ }^{20}$. „Pravda” veergudel ilmus ka rida juhtartikleid Eesti töölisliikumise küsimustes.

„Pravda” võitles selle eest, et katta kogu Venemaa töölisorganisatsioonide ja töölisajalehtede võrguga. Eriti tähtis oli emakeelsete töölisajalehtede ilmumine rahvuslikes ääremaades, kus valdav enamik töölisi ja talupoegi ei môistnud vene keelt ega saanud lugeda „Pravdat”. Uks esimesi sääraseid ajalehti oli „Kiir”, mis ilmus Narvas 15. juunist 1912. aastal kuni 12. juulini 1914. aastal.

Ajaleht „Kiir” hakkas ilmuma Narva sotsiaaldemokraatliku rühma initsiatiivil. Siin oli kergem kui Tallinnas teostada töölisajalehe väljaandmist, sest Narva kuulus Peterburi kubermangu ja siia ei ulatunud Eestimaa kuberneri Korostovetsi julm režiim.

Narvas oli tol ajal väike rühm bolševikke, kes töötas ametiühinguis ja „,Rahvahariduse Uhingus”. See rühm koondus hiljem „Kiire” ümber. Eestimaa parteiorganisatsioon oli siis veel ideeliselt ja organisatsiooniliselt nõrk. Seetõttu oli ka ajaleht algul nõrk ega olnud veel järjekindlalt bolševistlik.

Ajaleht „Kiir” seadis juba algusest peale oma eesmärgiks tööliste klassiteadvuse tõstmise ning töölisklassi revolutsioonilise vốitluse organiseerimise kehtiva korra kukutamiseks. Ta oli parteiline ajaleht, kaitses partei põrandaaluse töö vajadust ning aitas tugevdada partei mõju rahvahulkades. Kuid tal polnud algul täpset, selget ja järjekindlat platvormi, ta ei asetanud kogu oma agitatsioonilise töö keskpunktiks bolševistlike põhiloosungite kaitsmist. Ajalehe peamiseks puuduseks oli tema ideeline ebaküpsus, kokkulepluse esinemine nii teoreetiliste küsimuste käsitluses kui ka praktilises parteilises tegevuses.

Reast artiklitest kostis veel üleskutseid fraktsioonilisest võitlusest·loobumiseks, partei intelligentsete jõudude ühendamiseks, sotsiaaldemokraatide poolt kodanlikule ajakirjandusele tehtava kaastööga leppimiseks jne. ${ }^{21}$.

Hiljem saadi puudustest ja eksimustest üle ning ajaleht „Kiir” muudeti tõeliselt pravdistlikuks ajaleheks. See toimus oportunismi ja kokkulepluse vastu peetud kestva võitluse tulemusena.

„Kiire” olemasolu esimese poole aasta jooksul oli selle tegelikuks toimetajaks Villem Buk - proletaarne kirjanik - bolševik, 1905. aasta revolutsioonist osavõtja. Ta töötas „Kiires” aktiivselt kuni viimase sulgemiseni. 1912. aasta loopus sai ajalehe toimetajaks Eesti bolševistliku organisatsiooni väljapaistvamaid tegelasi Jaan Anvelt. Koos V. Kingissepaga võitles ta visalt

7 «Правда» № 37 от 14 февраля 1913 г.

18 Marxi-Engelsi-Lenini-Stalini Instituudi Partei Keskarhiiv, fond 17, säilitusühik 142.

19 «Путь правды», № 50 от 30 марта 1914 г.

20 Marxi-Engelsi-Lenini-Stalini Instituudi Partei Keskarhiiv, f. 17, sü. 54.

21 Vt. "Kiir" nr. 15, 21. sept. 1912. a. ja nr. 8, 19. jaan. 1913. a. 
selle eest, et muuta „Kiir" tõeliselt pravdistlikuks ajaleheks ja Eesti parteiorganisatsioon bolševistlikuks.

Reaktsiooniaastail pidasid bolševikud Eestis nagu kogu Venemaalgi visa võitlust menševike-likvidaatorite vastu. Selle võitluse tulemusena vähenes pidevalt likvidaatorite mõju sotsiaaldemokraatlike tööliste hulgas. Toimus sotsiaaldemokraatlike organisatsioonide bolševiseerumine. Reaktsiooniperioodi lõpuks suruti likvidaatorid teadlike töölistesotsiaaldemokraatide poolt parteitöö juhtimisest eemale. Kogu töö tegid töölised ise, kes otsustavalt toetasid bolševistlikku suunda. Menševikud enamasti intelligentsi esindajad, - kes olid tööliste hulgas võõrad, jäid massilisest töölisliikumisest eemale. Tõusuperioodi alguses polnud menševikel-likvidaatoreil Eestis mingisugust organisatsioonilist tuge, mingisuguseid häälekandjaid ega mingisugust tõsist mõju sotsiaaldemokraatlikes organisatsioonides ja rühmades, kogu Eestimaa töölisliikumises.

Menševikud rühmitusid Peterburi Eesti Úliõpilaste Seltsi ümber. Mõned nendest, näiteks A. Rei, avaldasid aktiivsust, esinesid loengutega Eestis ning püüdsid mõju avaldada legaalseile töölisorganisatsioonidele, kuid töölised ei läinud nendega. Uksikuid menševikke oli ka ettevõtetes, kuid nad ei leidnud tööliste poolt toetust.

Likvidaatorluse kodanlik olemus avaldus sel perioodil eriti ilmselt, sest likvidaatorid toetasid kodanlik-natsionalistlikku "Noor-Eesti” liikumist, mis astus avalikult välja revolutsioonilise marksismi ja eesti töölisajalehe vastu.

Parteiorganisatsioonide bolševiseerimine toimus eelkõige oportunismisse leplikult suhtumisest vabanemise liinis, et luua tingimused täielikuks ja otsustavaks eraldumiseks iga liiki oportunistidest kogu parteis ja kõigis tema organisatsioonides. Peeti otsustavat võitlust selle vastu, et sotsiaaldemokraadid teevad kaastööd kodanlikule ajakirjandusele ning maskeeritud likvidaatorluse vastu, mis ilmnes Tallinna organisatsioonis ning väljendus Tallinna komitee liikme A. Kastra ja tema väheste poolehoidjate tegevuses.

Ajaleht „Kiir” ilmus esimestest numbritest alates VSDT (b) P Tallinna komitee häälekandjana, kuid komitee mitte üksnes ei juhtinud ajalehte, vaid hakkas varsti koguni selle tööd pidurdama. See on seletatav Kastra õonestustööga Tallinna komitees. VSDT(b)P Tallinna komitee liige August Kastra rikkus partei otsust, et sotsiaaldemokraatide osavõtt kodanlikust ajakirjandusest pole lubatav ${ }^{22}$, ning hakkas kodanliku ajalehe ,Tallinna Teataja" toimetuse liikmeks ja töölisosakonna toimetajaks.

Ajaleht ,Tallinna Teataja” oli eesti kodanluse selle osa hääletoruks, kes pidas niinimetatud edumeelsete parteid, eesotsas Tõnissoniga, ja selle liini liiga avalikuks, avameelselt kodanlikuks, mis tõukab töölised eemale. Rühm eesti kodanlikke liberaale, eesotsas Pätsiga, kes olid ühinenud „Tallinna Teataja" ümber, püüdsid kodanluse võimu peenemalt kaitsta. Tema tegelased püüdsid end näidata ,tööliste sõpradena”, nad lõid töölisliikumises oma agentuuri, meelitades enda teenistusse sotsialismi renegaate, ning kirjutasid töölisliikumise küsimustest, mille eest neid nimetati sotsiaal-liberaalideks. Nad jutlustasid kodanlikku natsionalismi, et eesti töötajaid vene revolutsioonilistest töölistest eemale kiskuda.

Kastra töötas kodanliku ajalehe juures peibutisena tööliste jaoks, inimesena, kes on seotud töölisliikumisega. Kastra üheaegne osavõtt VSDT (b) P Tallinna komiteest ja kodanliku ajalehe toimetusest desorienteeris töölisi, kes olid VSDT (b) Parteiga seotud, ning tõi 'parteile suurt kahju. Hoolimata

22 Решенне 4-ой конференции 1907 г. - КПСС в резолюциях стр. $185-186$.
РСДРП (жТретьей Общероссийской») в ноябре съездов, конференций и пленумов ЦК, ч. I 
sellest, ei aetud Kastrat Tallinna komiteest minema, mis on seletatav kokkulepluse mõjudega Tallinna parteiorganisatsioonis.

Kuni „Kiire” ilmuma hakkamiseni vabandas Kastra oma tööd „Tallinna Teataja" juures sellega, et Eestis polevat töölisajalehte. Nüüd langes see põhjendus ära. Kuid Kastra keeldus üle minemast tööle ajalehe „Kiir” juurde, mille toimetuse liikmeks teda loeti, ning pidas oma peremeeste käsul vōitlust Eesti revolutsiooniliste jõudude koondumise keskpunktiks kujuneva töölisajalehe vastu.

Algul Kastra saboteeris ajalehe väljaandmist, pärast aga asus „Kiirt” avalikult ründama.

Seoses trükitööliste üldstreigiga laimas kodanlik ajaleht „Päevaleht” trükitöölisi. See kutsus esile Tallinna töötajate meelepaha. Siis avaldas Tallinna komitee „Päevalehe” vastu protesti allkirjaga „Paljud Tallinna töölised" ning kutsus üles lehte boikoteerima. Kuid see protest ei saavutanud eesmärki, sest ta avaldati mitte töölisajalehes, vaid „Tallinna Teatajas" ning tähendas tegelikult ühe kodanliku ajalehe toetamist teise vastu.

Ajaleht „Kiir" võttis „Paljude Tallinna tööliste” selle eksisammu kriitika alla. Siis astus Kastra rühm välja kallaletungidega „Kiire” vastu ning tegi Tallinna tööliste hulgas „Kiirele” vaenulikku kihutustööd ${ }^{23}$. Säärane lōhestav, õõnestav tegevus sai otsustava vastulöögi bolševistlikelt organisatsioonidelt, kes toetasid „Kiirt” ${ }^{24}$. Töölisliikumise desorganiseerijate vastases võitluses tuli „Kiirele” appi „Pravda”, kes kirjutas: „Töölisajalehte jälitavad võimud; toimetus ja väljaandjad, viibides äärmises puuduses, on töökoorma all nõrkemas, et mitte lasta hääbuda töölisklassi kõige vajalikumat võitlusrelva; eestlastest töölised teostavad kõigis linnades korjandusi oma häälekandja heaks ning neile tulevad solidaarsusest sagedasti appi ka vene ja läti seltsimehed. Tallinnas aga propageerivad meie ainsad organiseeritud sotsiaaldemokraatlikud seltsimehed oma klassi ainsa häälekandja vastast aktiivset boikotti, korjavad vabrikuis allkirju paadunud renegaadi hr. Kastra kaitseks... Muidugi ei või säärane poliitilise teadlikkuse langus Tallinna tööliste hulgas kaua kesta. Uha eñam tugevneb seal vool töölisajalehe poolt ja nende vastu, kes on reetnud oma klassi suure ürituse" 25 .

Kastra desorganiseeriva tegevuse vastu astusid välja Tallinna teadlikud töölised. Tallinna tehaste töölised-bolševikud suurendasid „Kiirele” antavat abi ja aitasid kaasa ajalehe levikule.

Kastra teostas tegelikult likvidaatorlikku poliitikat: ta ei teinud põrandaalust tööd ning eemaldus partei tööst vabrikuis ja tehaseis. Ta asus otseselt kodanluse teenistusse, lōhestas töölisklassi ning vedas teda liberaalse töölispoliitika rappa, s. o. tal polnud proletariaadi revolutsioonilise parteiga midagi ühist. Ta astus välja illegaalsete lendlehtede väljaandmise ning bolševistliku miinimumprogrammi revolutsiooniliste loosungite vastu, eriti mõisamaade konfiskeerimise loosungi vastu ${ }^{26}$. Kuid bolševike partei revolutsioonilise programmi ja taktika vastu välja astudes nimetas ta ennast bolševikuks, parteilaseks ning kuulutas likvidaatoreiks „Kiire” poolehoidjaid. Ta kirjutas Ríigiduuma bolševistlikule fraktsioonile ning VSDT(b)P Keskkomiteele kirju, milles ta laimas tõelisi bolševikke, püüdis juhtivaid parteiorganeid desinformeerida ning saada neilt toetust ${ }^{27}$. Kastra silmakirjalik käitumine, kes astus välja likvidaatorite vastase võitleja maski all, viis osa Tallinna töölistest teatud aja jooksul segadusse ning raskendas

23 „Kiir” nr. 33, 20, dets. 1912, a.

24 "Kiir" nr. 36, 29. dets. 1912. a, nr. 2, 5. jaan. 1913. a. ja nr. 3, 8. jaan. 1913. a.

25 «Пролетарская правда» № 8 от 11 января 1914 г. sü. 200 ,

26. Marxi-Engelsi-Lenini-Stalini Instituudi Partei Keskarhiiv, ${ }^{\top}$ fond 17, nimistu 2,

27 Sealsamas. 
võitlușt Kastra ja tema poolehoidjate vastu ja parteiorganisatsioonide puhastamist nendest maskeeritud likvidaatoritest.

Ajaleht „Kiir” aitas Tallinna töölistel varjatud likvidaatorite antimarksistlikust tegevusest aru saada. Ta selgitas bolševike partei strateegiat ja taktikat, pidas, eriti 1913. aasta lõpust alates, otsustavat ideelist võitlust marksismi vaenlaste vastu ning propageeris marksismi ideid laiades rahvahulkades. Uhtlasi tegi ta suurt organisatsioonilist tööd. Selle suure töö tulemusena saavutati Tallinna sotsiaaldemokraatlike organisatsioonide bolševiseerimine ja nende täielik lahkulöömine Tallinna komitee likvidaatoreist oportunistidest. „Kiire” toimetus suunas Tallinna hea parteiorganisaatori Hindrik Suuderi, kelle juhtimisel hakkas bolševike organisatsioon kiiresti suurenema ja tugevnema.

Aastail 1912-1913 tegid Tallinna, Narva, Tartu ja Pärnu bolševike parteiorganisatsioonid Peterburi eesti bolševike aktiivsel kaasabil ära suure töö. Nad teostasid revolutsioonilist agitatsiooni rahvahulkades, organiseerisid tööliste streike ja demonstratsioone, levitasid „Pravdat”, „,Kiirt” ja teisi bolševistlikke väljaandeid ning töötasid legaalsetes organisatsioonides - ametühinguis, haigekassades, karskusseltsides, tööliskooperatiivides ja kultuurhariduslikes seltsides. Organisatsioonid kasvasid ja nende mõju tugevnes. Nad sooritasid suure töö seoses IV Riigiduuma valimistega, selgitasid Duuma bolševistliku fraktsiooni võitluse mõtet, juhtisid tööliste kindlustamiskampaania läbiviimist jne. Illegaalse töö ühendamine legaalsete võimaluste oskusliku kasutamisega laiendas parteiorganisatsioonide sidet massidega ja tugevdas nende mõju.

Eesti parteiorganisatsioonid pidasid otsustavat vōitlust eesti kodanluse ja tema kodanlik-natsionalistliku ideoloogia vastu.

Teatavasti tõstis mustasajalise natsionalismi märatsemine ning natsionalistlike tendentside kasv rōhutud rahvaste ülemiste kihtide hulgas imperialistliku sōja eel üheks tähtsamaks küsimuseks rahvusküsimuse.

Eesti kodanlus, kartes töölisklassi kasvavat liikumist, püüdis tööliste teadvust mürgitada natsionalismi mürgiga. Kodanlike natsionalistide valelik jutlustamine eesti rahva terviklusest ja tema kultuuri ,ühtsusest”, nende püüe kujutada kodanlust rahvuse huvide tõelise kaitsjana sai otsustava vastulöögi bolševike ja nende ajalehe „Kiire” poolt. Bolševikud astusid välja natsionalistliku kampaania vastu, mida teostati seoses laulupeoga. Nad vōitlesid kodanliku natsionalismi propaganda vastu ühiskondlik-poliitilisel alal ning kirjanduse ja kunsti küsimustès, paljastasid „Noor-Eesti” kodanlikku olemust ning kodanlíku liberalismi ohtu. Kõige paremad artiklid kodanliku natsionalismi vastu kirjutas V. Kingissepp. Ajaleht „Kiir” juhindus selles võitluses partei programmist, V. I. Lenini töödest ja Praha konverentsi ning Krakovi ja Poronini nõupidamiste otsustest rahvusküsimuses.

Vastavalt parteiorganisatsioonide tugevnemisele ning ajalehe „Kiir" väljakujunemisele kasvas partei aktiivsete pooldajate arv. Sellest annab tunnistust „Kiire” heaks „Pravda” eeskujul organiseeritud korjanduste kasv.

Kui 1912. aasta teisel poolel pandi „Kiire” heaks toime 26 korjandust, siis aasta hiljem, 1913. aasta teisel poolel, oli neid juba 135.

„Kiire” ilmumise esimesel aastal teostati 117 korjandust, teisel aastal aga $263^{28}$. Paljudes tervitustes avaldasid töölised oma poolehoidu ajalehele. Ajaleht „Kiir”, mis muutus revolutsioonilise tegevuse keskuseks,

28 Aruandeid korjanduste kohta avaldati „Kiires” süstemaatiliselt. Arvestus on tehtud „Kiire” ja tema järelkäijaté järgi kogu ajalehe ilmumise aja jooksul - 15. juunist 1912. a. kuni 12. juulini 1914. a. 
tugevdas ja laiendas lakkamatult oma sidemeid massidega - tööliste, sulaste ja kehvtalurahvaga. Ajalehe korrespondentide võrk muutus üha laiemaks. Nii avaldas „Kiir” 1912. aasta teisel poolel kaastööd 37 kohast Eestis, 1913. aasta esimesel poolel aga juba 44 kohast, 1913. aasta teisel poolel - 66 kohast ja 1914. aasta esimesel poolel - 77 kohast ${ }^{29}$.

Peab märkima, et üha rohkem kaastööd saabus „Kiirele” maalt. Sulased ja vähese magga talupojad toetasid aktiivselt ajalehte, mis kaitses revolutsioonilisi loosungeid, näidates töötavale talurahvale ainsat õiget teed võitluseks parema elu eest. Ajaleht võitles töölisklassi ja talurahva liidu ja kodanluse isoleerimise eest.

Ajaleht „Kiir" koondas enda ümber laialdase aktiivi, mis koosnes korrespondentidest, ajalehe levitajaist, tellimuste organiseerijaist, raha kogujaist töölisajakirjanduse fondi ja lugejaist ning kasvatas revolutsioonilisi töölisi - bolševismi poolehoidjaid, pravdiste, kiire-mehi.

Ajalehe „Kiir" suhtes teostati karme repressioone. Oma ilmumise aja jooksul suleti ta 5 korda ning iga kord sündis ta uuesti teise nime all: „Narva Kiir”, „Rahvaleht”, „Töö Hääl” ja „Töö Kiir”.

Rahena langesid ajalehele konfiskeerimised, trahvid ning toimetajate ja väljaandjate arreteerimised. Nendes tingimustes sai ajaleht eksisteerida vaid tänu sellele lakkamatule abile, mida talle osutasid töölised oma korjandustega. Ajalehele materiaalse abi andmisel etendas ka tähtsat osa legaalse kirjastusühingu „Rahva Sõna” organiseerimine bolševike poolt, mis varjas ajalehe „Kiir” juhtimist põrandaaluse parteiorganisatsiooni poolt.

Ajaleht „Kiir” kujunes sidemete korraldajaks Narva, Tallinna, Tartu, Peterburi jt. parteiorganisatsioonide vahel. Kuid need sidemed polnud sugugi küllaldased, organisatsioonide killustätus ning üle-eestilise parteikeskuse puudumine andis end teravalt tunda. Parteiorganisatsioonide killustatus ja kindlate kohalike parteikeskuste puudumine andis ennast tunda ka parteis tervikuna ${ }^{30}$, mispärast VSDT(b) P Keskkomitee Poronini nõupidamine parteitöötajatega tunnistaski kõige tähtsamaks organisatsiooniliseks ülesandeks, ,mitte ainult juhtivate parteiorganisatsioonide tugevdamise igas linnas, vaid ka üksikute linnade organisatsioonide ühendamise omavahel. ${ }^{31}$

Eesti parteiorganisatsioonide killustatuse likvideerimisel oli tõsiseks sammuks "Rahva Sõna” osanike konverents 6.-8. oktoobrini 1913. aastal Peterburis, V. Kingissepa juhtimisel. Sellel konverentsil esinesid Tallinna esindajad teadaannetega bolševistlike organisatsioonide tööst „Dvigatelis” ja „Lutheris” ning võitlusest Tallinna komitee oportunistide vastu; koostati ka plaan väljaastumiseks 16 . oktoobril.

Konverents töötas välja abinõud ajalehe „Kiir” tegevuse arendamiseks ja tema levitamise parandamiseks.

Konverents aitas kaasa „Kiire” lõplikule muutmisele järjekindlaks bolševistlikuks häälekandjaks ning bolševistlike jõudude tugevnemisele Tallinnas ${ }^{32}$.

Sotsiaaldemokraatliku duruma fraktsiooni lõhenemine 1913. aasta oktoobris soodustas selgema piiri tõmbamist bolševike ja partei vaenlaste vahele ning kokkuleplusest ülesaamist igal pool, sealhulgas ka Eestis.

29 Arvestus on tehtud „Kiire” ja tema järelkäijate pōhjal kogu ajalehe ilmumise aja jooksul.

30 Sellest kirjutab ka N. K. Krupskaja oma kirjas Guštš’ile (Stassovale) 1913. a. märtsis. Vt. Marxi-Engelsi-Lenini-Stalini Instituudi Partei Keskarhiiv, f. 17, sü. 29.

з КПСС в резолюциях и решениях съездов, конференций и пленумов ЦК. Часть I, стр. 310.

32 Riiklik Ajaloo Keskarhiiv Moskvas, Politseidepartemangu fond (f. 102-oo), säilitusühik 5, 93. osa, lit. Б, aasta 1913, lehed 101-104. - Sealsamas, sü. 259, 93. osa, a. 1913, lehed 6-9. - Sealsamas, 7. osakond, sü. 1548, a. 1913, 1. 6. 
See lõhenemine seadis teravalt üles küsimuse: kas kuue saadiku-marksisti, s. o. bolševike, või seitsme likvidaatorlusele kalduva saadiku, s. o. menševike poolt. Iga sotsiaaldemokraatliku organisatsiooni, iga parteiliikme ette tõusis küsimus: kas bolševike partei, ilma menševike-likvidaatoriteta uut tüüpi partei poolt või oma ridades oportuniste salliva lääne-euroopalikku tüüpi partei poolt. Tõusis küsimus, kas võib lubada leppimist oportunismigà. Fraktsiooni lõhenemine seadis iga parteiorganisatsiooni ette praktilise küsimuse Praha konverentsi otsuste teostamise kohta. Valdav enamik Eesti sotsiaaldemokraate langetasid otsuse kuue saadiku poolt ja seitsme saadiku vastu ning tervitasid palavalt saadikuid-bolševikke ${ }^{33}$.

VSDT(b) P Keskkomitee aitas Eesti bolševikel lōplikult lahku lüüa oportunistidest, teha lōpp kokkuleplusele ning tugevdada oma organisatsiooni. VSDT(b) P Keskkomitee ja V. I. Lenin isiklikult osutasid Eesti parteiorganisatsióoni suhtes suurt hoolitsust, neid tegi rahutuks organisatsiooni nõrkus ja regulaarse informatsiooni puudumine Eestist.

Keskkomitee istungil, mis toimus 1913. aasta oktoobri alguses, kohe pärast Poronini nõupidamist, otsustati teha saadikuile ülesandeks sooritada ringreis kohalikesse organisatsioonidesse, ning G. I. Petrovski pidi külastama Baltimaid. G. I. Petrovski oma mälestustes räägib, et V. I. Lenin tegi talle ülesandeks aidata Eesti bolševikel orienteeruda käesoleva momendi olukorras, tutvustada neid Keskkomitee ja parteitöötajate nõupidamise otsustega ning informeerida Keskkomiteed olukorrast Eestis ${ }^{34}$.

Samal ajal võtsid Eesti bolševikud 1913. aasta teisel poolel omalt poolt tarvitusele otsustavad abinõud sidemete loomiseks partei Keskkomiteega. Nad lõid tihedad sidemed bolševistliku duumafraktsiooniga ning seadsid fraktsiooni ette küsimuse Eesti töölisajalehe tunnustamisest bolševike partei kohalikuks häälekandjaks, VSDT (b) P Keskkomitee kontrolli sisseseadmisest ajalehe üle, fraktsiooni osavõtust aja väljaandmisel ning vene literaatide alatisest kaastööst ajalehele. Ajalehe suuna tutvustamiseks tõlkis $\mathrm{V}$. Kingissepp vene keelde enam kui poolsada ajalehe artiklit ja juhtkirja ${ }^{35}$. Oma kirjades fraktsioonile kirjutas V. Kingissepp Eesti parteiorganisatsioonide nõrkusest ja määratu suurtest raskustest, millega tuleb „Kiirel” võidelda, ning palus fraktsioonilt ja partei Keskkomiteelt abi ${ }^{36}$. Fraktsioon tutvustas VSDT(b) P Keskkomiteed kõigi nende materjalidega ning sidus Eesti bolševikud partei Keskkomiteega ${ }^{37}$.

Bolševistliku duumafraktsiooni sekretär E. F. Rozmirovitš kirjutas 5. veebruaril 1914. aastal VSDT(b) P Keskkomiteesse:

„Saadan teile lähemail päevil materjalid, mida meile esitasid eestlased.

„Töö Hääle” toimetuse esindaja pöördus meie poole ettepanekuga vôtta nende häälekandja oma kontrolli alla. Mitte üksnes pravlentside ${ }^{38}$, vaid ka teie kontrolli alla.

Ma tutvun nüüd kõigi materjalidega, mis nad meile esitasid, et anda

33 «За правду» № 50 от 3 декабря 1913 г.-«Пролетарская правда» № 13 от 21 декабря 1913 г. - «уть правды» № 50 от 30 марта 1914 г.

34 Riiklik Ajaloo Keskarhiiv Moskvas, Politseidepartemangu fond (f. 102-oo), nim. 238 , sü. 5 , järg 4 , а. 1910 , lehed $473-474$ - Г. И. П е т р о в к и й, По заданию Ленина. «Советская Эстония» от 30 апреля 1947 г.

${ }_{35}$ Marxi-Engelsi-Lenini-Stalini Instituudi Partei Keskarhiiv, fond 448, nimistu 1, säilitusühik 37362. - Sealsamas, f. 17, sü. 66. - Riiklik Ajaloo Keskarhiiv Moskvas, Politseidepartemangu fond (f. 102-oo), sü. 5, 93. osa, lit. Б, a. 1914, 1. 34. - EKP Keskkomitee Partei Ajaloo Instituudi käsikirjade fond. Mälestuste raamat, nr. 19, 1. 30.

36 Marxi-Engelsi-Lenini-Stalini Instituudi Partei Keskarhiiv, f. 448, nim. 1, sü. 37362 . - Sealsamas, f, 17, sü. 97.

37 Sealsamas, sü. 66 . - Sealsamas, sü. 97.

38 „Pravlentsid" - fraktsiooni konspiratiivne nimetus. 
neile vastus pravlentside osavõtu kohta sellest üritusest. Vastake ka teie rutem. Võin neid viia vahetusse kontakti teiega" ${ }^{39}$.

Täites VSDT (b) P Keskkomitee poolt pandud ülesannet saabus G. I. Petrovski 22. märtsil 1914. aastal Tallinna. Tema juhatusel toimus Eesti parteilaste-sotsiaaldemokraatide nõupidamine. Nõupidamisest võttis osa 10 inimest: kuus esindajat Tallinnast, kaks Narvast, üks Tartust ja üks Helsingist.

Nõupidamisel kuulati ära G. I. Petrovski ettekanne olukorrast parteis ning Venemaa Sotsiaaldemokraatliku Töölisfraktsiooni tegevusest. Kõneleja tutvustas kokkutulnuid partei Krakovi ja Poronini nõupidamiste otsustega ja partei järjekordsete ülesannetega. Eesti bolševike nõupidamine kiitis need otsused heaks ning tunnistas partei positsiooni „õigeks ja järjekindlaks, mis püüab võidelda kärpimata loosungite eest" 40.

Nõupidamine kiitis.Venemaa Sotsiaaldemokraatliku Töölisfraktsiooni tegevuse heaks ning tervitas kuut saadikut-bolševikku nende ,püsiva ja visa võitluse" eest ${ }^{41}$.

Nõupidamine tunnistas vajalikuks, et Eesti töölisorganisatsioonid seaksid sisse tihedad sidemed VSDTP fraktsiooniga, ning saatis talle informatsiooni kõigist sündmustest seoses töölisliikumisega ${ }^{42}$.

Ära kuulanud kohalike esindajate ettekanded, märkis nõupidamine revolutsioonilise liikumise kasvu, mis tungivalt nõuab parteiorganisatsioonide tugevdamist ja koondamist, ning tunnistas vajalikuks lähemal ajal kokku kutsuda Eesti parteikonverents ning luua parteikeskus.

Kohalike esindajate ettekannete alusel vastuvõetud resolutsioonis märgiti, et on hädavajalikud ,kõige tihedamad sidemed vene seltsimeestega ja eriti Peterburi töölistega, samuti ka kõige tihedam ühendus töölisajalehe "Kiir" ja „Pravda” vahel ${ }^{43}$.

Edasi arutas nõupidamine ajalehe „Kiir” küsimust ning tunnistas ta partei häälekandjaks. Resolutsioonis on selle küsimuse kohta öeldud: „Nõupidamine leiab, et ajaleht ,Kiir” on marksistlik töölisajaleht, et ta tuleb allutada VSDT Partei kontrollile" ${ }^{44}$. Nõupidamine kohustas ajalehe toimetust astuma VSDTP fraktsiooniga tihedamaisse suhetesse. Nõupidamisel teatas toimetuse esindaja J. Anvelt, et ta loeb nõupidamise otsust enda suhtes kohustuslikuks ${ }^{45}$.

Lõpuks arutas nõupidamine Kastra ja Tallinna komitee käitumist ning nõudis Tallinna komitee laialisaatmist ja uue komitee valimist. Resolutsioonis on selle küsimuse kohta öeldud: „Arvesse võttes, et hr. Kastra, kes kuulutab end marksistliku töölisliikumise eestvõitlejaks, on samal ajal toimetuse liikmeks (ja isegi osanikuks) kodanliku ajalehe „Tallinna Teataja” juures, mis kiusab taga töölisajalehte „Kiir”;

et hr. Kastra säärane lubamatu käitumine ja tema avalik agitatsioon nimetatud töölisajalehe vastu desorganiseerib eesti tööliste ridasid ning tumestab nende klassiiseteadvust ja et VSDTP Tallinna komitee toetab ja kaitseb hr. Kastra selliseid väljaastumisi, palub nõupidamine kõrgemat asutust küsida Tallinna komiteelt, millega ta seletab säärast suhtumist hr. Kastrasse.

Nõupidamine teeb ettepaneku Tallinna komitee laiali saata ning mää-

39 Marxi-Engelsi-Lenini-Stalini Instituudi Partei Keskarhiiv, f. 17, sü. 66.

40 Sealsamas, f. 17, sü. 54. - Резолюция совещательного собрания социал-демократов - партийщев Эстляндии, 1. 2.

41 Sealsamas, I. 1.

42 Sealsamas, 1. 4.

4. Sealsamas, 1. 2.

44 Sealsamas, 1. 3.

15 Sealsamas. 
rata uued valimised, millest peavad osa võtma kõigi Tallinna rajoonide kõik parteilased" 46 .

Eesti sotsiaaldemokraatide-parteilaste nõupidamisel oli määratu suur tähtsus Eesti bolševistliku organisatsiooni jaoks ja tal on tähtis koht Eestimaa Kommunistliku Partei ajaloos. Ta viis bolševike lõplikule lahkulöömisele oportunistidest ning valmistas ette kohaliku parteikonverentsi kokkukutsumist.

Nõupidamise otsused kiideti heaks IV Riigiduuma bolševistliku fraktsiooni poolt, kes varsti pärast nõupidamist kuulas oma koosolekul ettekannet ajalehe „Kiir” kohta ${ }^{47}$ ning otsustas tunnistada „Kiir” bolševistlikuks häälekandjaks ning anda talle materiaalset abi.

Oma koosolekul, mis toimus 6. ja 8. aprilli vahel, kinnitas VSDTP Keskkomitee selle otsuse ja määras eesti töölisajalehele rahalist toetust 200 rubla suuruses, mis anti toimetusele ${ }^{48}$.

Seega tunnistati ajaleht „Kiir” VSDTP Keskkomitee otsusega ametlikult bolševistlikuks partei häälekandjaks.

Täiesti pōhjendatult mainis ajaleht „Rabotši” nr. 1, mis oli pühendatud töölisajakirjanduse päevale 22. aprillil 1914. aastal, oma artiklis legaalse töölisajakirjanduse kohta ka ajalehte „Kiir” pravdistliku suunaga legaalsete töölishäälekandjate hulgas ${ }^{49}$. V. I. Lenin aga nimetas eesti töölisajalehte otseselt pravdistlikuks ${ }^{50}$.

Nõupidamise otsus kiideti kohalike partei organisatsioonide poolt palavalt heaks ${ }^{51}$.

Tallinna bolševikud hakkasid kohe pärast nõupidamist organiseerima uut Tallinna komiteed. Aprillis toimusid Tallinna laevaehitustehastes, sadamas, „Dvigatelis”, „Krullis” ja mujal uue bolševistliku Tallinna komitee valimised ${ }^{52}$.

Samal ajal ei lõpetanud lüüasaanud oportunistid võitlust, vaid püüdsid veel Tallinna töölisi oma mõju alla saada. 13. aprillil kokku tulnud, rääkisid nad sellest, kuidas kogemusteta töölisi-bolševikke ära kasutades uuesti enda juhtimisel organiseerida Tallinna linnakomitee. Töötati isegi välja plaan, et juhtumil, kui bolševike Keskkomitee võtab tarvitusele abinõud oportunistide tegevuse lõpetamiseks, tuleb luua organisatsioon föderatiivsel alusel ning ühineda Soome organisatsiooniga ${ }^{53}$. Uhtlasi jätkasid oportunistid oma kallaletunge eesti töölisajalehele.

Kastra rühmal polnud tööliste hulgas edu. Kui ta 1914. aasta maikuul tegi katset luua oma linnakomitee, vastukaaluks bolševistlikule Tallinna

46 Marxi-Engelsi-Lenini-Stalini Instituudi Partei Keskarhiiv, f. 17, sü. 54. Резолюция совещательного собрания социал-демократов - партийцев Эстляндии, 1. 5.

47 Ettekandega esines Jelizaveta Kingissepp (Lell) - V. Kingissepa naine, kes tollal pidas V. Kingissepa ülesandel sidet fraktsiooniga, sest V. Kingissepp, olles mõistetud Peterburist väljasaatmisele, pidi ennast varjama ja sõitis Helsingisse - Vt. J. Kingissepa mälestused, EKP Keskkomitee Partei Ajaloo Instituudi käsikirjade fond, Mälestuste raamat nr. 19, 1k. 30. - Marxi-Engelsi-Lenini-Stalini Instituudi Partei Keskarhiiv, f. 448 , nim. 1, sü. $37362,1.2$.

48 Riiklik Ajaloo Keskarhiiv Moskvas, Politseidepartemangu fond (f. 102-oo), nim. 238, sü. 5 , järg 4, a. $1910,1.287$. - Sealsamas, sü. 307 , järg 1, a. 1914, lehed 209, 299. «Спутник рабочего» на 1914 г.

49 «Рабочий» № 1 от 22 апреля 1914 г., статья «Легальная рабочая печать в Россин».

${ }_{50}$ V. I. L e n i n, Teosed, 20. kd., 1k. 353. Sel ajal kui avaldati V. I. Lenini artikkel (ajalehes „Trudovaja Pravda" nr. 27, 28, juunist 1914), ilmus eesti töölisajaleht „Töö Kiire" nime all.

51 EKP Keskkomitee Partei Ajaloo Instituudi käsikirjade fond. Sm. Sisaski mälestused.

52 Riiklik Ajaloo Keskarhiiv Moskvas, Politseidepartemangu fond (f. 102-oo), sü. 5, 93. osa, lit. Б, a. 1914, lehed $42-43,48$.

53 Sealsamas, lehed $37-38$. 
komiteele, siis läks tal suurte raskustega korda kaasa tõmmata esindajaid vaid kolmest ettevõttest: Lutheri vabrikust, tselluloositehasest ja Mayeri tehasest ${ }^{54}$, kuid need esindajad ei väljendanud ettevõtete sotsiaaldemokraatlike tööliste enamuse tahet.

1914. aasta märtsi lõpus ja aprillis hakkas Eesti bolševistlik organisatsioon tegema ulatuslikke ettevalmistusi 1 . maiks. Korraldati põrandaaluseid parteikoosolekuid ning kavatseti aprilli lõpus Tallinnas korraldada suur ülelinnaline nõupidamine, mis aga nurjus massiliste arreteerimiste tõttu ööl vastu 25. aprilli.

Bolševistlik Tallinna komitee valmistas aegsasti ette ja trükkis Narvas esimese mai lendlehti eesti ja vene keeles ${ }^{55}$. Neid lendlehti levitati laiemalt kui eelmisi ning suuremal arvul (umbes 1500 eksemplari) ${ }^{56}$.

1914. aasta 1. mai proklamatsioon oli esimeseks täiel määral bolševistlikuks proklamatsiooniks sellel perioodil. Bolševikud kutsusid töölisi üles üldstreigiks loosungite all: „Olgu tervitatud 1. mai! Maha isevalitsus! Elagu demokraatlik vabariik! Elagu 8-tunnine tööpäev! Elagu kõigi mõisamaade täielik konfiskeerimine! Elagu VSDTP!" ${ }^{57}$. Esimese mai streik Tallinnas oli peaaegu üldine ning temaga käisid kaasas miitingud ja demonstratsioonid Vene-Balti tehase juures ja Viru tänaval ${ }^{58}$.

Tartus levitati 1. mai eelōhtul lendlehti, milles nõuti suuremat palka ja 8-tunnist tööpäeva ${ }^{59}$. 30 . aprilli õhtul organiseerisid bolševikud Tähtvere pargis miitingu, kus peeti kõnesid 1. mai tähtsusest ja järjekordseist revolutsioonilistest ülesannetest. Seejärel toimus Toomemäe kaudu linna rongkäik, millest võttis osa umbes 300 inimest. Demonstrandid hüüdsid revolutsioonilisi loosungeid: „Maha isevalitsus!”, „Elagu revolutsioon!” Politsei ajas demonstrandid laiali. 1. mail tehti katset korraldada Tähtvere metsas 1. mai meeleavaldus, kuid politsei ja ratsapolitsei ajasid kokkutulnud inimesed laiali. Seega organiseerisid bolševikud esimese avaliku poliitilise väljaastumise Tartus ${ }^{60}$.

Narvas pandi välja 1. mai ööl punased lipud. Kuressaares ja reas mõisates levitati esimese mai lendlehti ${ }^{61}$.

Esimese mai väljaastumised andsid tunnistust bolševistlike organisatsioonide tugevnemisest ja nende suurenenud mõjust töölisklassi hulgas.

Bolševistlik Tallinna komitee laiendas oma tööd ning korraldas rea pōrandaaluseid koosolekuid.

Suur koosolek toimus 18, mail 1914. aastal Pirita metsas H. Suuderi juhtimisel. Arutati liikmemaksu suuruse, illegaalse ja legaalse töö ühendamise ning Malinovski Riigiduumast lahkumise küsimust. Kõigis küsimustes võeti vastu bolševistlikud otsused ${ }^{62}$.

Eriti mõistsid Tallinna töölised koos Venemaa kõigi eesrindlike töölistega teravalt hukka Malinovski reetlikku käitumist ning avaldasid Venemaa sotsiaaldemokraatlikule töölisfraktsioonile täielikku usaldust ja toetust ${ }^{63}$.

54 Riiklik Ajaloo Keskarhiiv Moskvas, Politseidepartemangu fond (f. 102-oo), sü. 5, 93. osa, lit. Б, a. 1914,1 , 50 .

55 Sealsamas, 9. osakond, sü. 844 , a. 1914, 1. 17. - Sealsamas, f. 102-oo, sü. 5, 93. osa,

lit. E, a. 1914, lehed $42-43$.

56 Sealsamas, f. 102-oo, sü. 5, 93. osa, lit. Б, a. 1914, lehed 42-43. - Sealsamas, 1. 45.

57 Sealsamas, 1. 45.

58 Sealsamas, 4. osakond, sü. 88,2 . osa, a. 1914, lehed $26,27$.

59 „Töö Hääl” nr. 50, 3. maist 1914.

60 ENSV RAKA, f. 330, sü. 2, 1. 424. - „Töö Kiir” nr. 1, 15. maist 1914. a. EKP Keskkomitee Partei Ajaloo Instituudi käsikirjade fond. Sm. Sisaski mälestused.

61 „Töö Hääl” nr. 51, 6. maist 1941. a.

62 Riiklik Ajaloo Keskarhiiv Moskvas, Politseidepartemangu fond (f. 102-oo), sü. 5, 93. osa, lit. Б, lehed $52-53$.

6з «Рабочий» № 3 от 24 мая 1914 г. 
Juunis toimus Tallinna parteiorganisatsiooni edasine organisatsiooniline tugevdamine. Linn jaotati kolmeks rajooniks: „Dvigateli” rajooniks, Linnaehk Keskrajooniks ja Kopli rajooniks, mis, valisid oma rajoonikomiteed tehaste esindajate hulgast. Rajoonide esindajad moodustasid Linnakomitee. Toimus elav ettevalmistus üle-eestiliseks parteikonverentsiks, mille kokkukutsumine oli ette nähtud partei nõupidamise otsuses.

Eesti bolševike konverents toimus 15. juunil 1914. aastal Paemurrus, Narva lähedal. Sellest võtsid osa Tallinna, Narva, Tartu, Pärnu ja Peterburi eesti organisatsiooni esindajad ${ }^{64}$. Päevakorras olid järgmised küsimused: 1) kohalike esindajate aruanded, 2) töölisajakirjandusest ja tema levitamisest, 3) käesolev moment, 4) parteikongressi kokkukutsumisest, 5) VSDTP ühtsusest, 6) Eesti Keskkomitee valimistest, 7) sotsiaaldemokraatide osavõtust ja taktikast haigekassades, kultuur-hariduslikes ühingutes ja ametiühingutes.

Esindajate aruannetest selgus, et Tallinnas on 125 parteiliiget, kes on organiseeritud 5-10-liikmelistesse parteigruppidesse. Kõige tugevamas „Dvigateli" parteiorganisatsioonis oli 25-30 inimest. Märgiti parteitegevuse paranemist Tallinnas ja teistes linnades.

Peterburi delegaadi aruandest selgus, et Peterburi Eesti organisatsioonis on 60 liiget. Ta kuulub Peterburi parteiorganisatsiooni koosseisu rajooni õigustega.

Eesti bolševike konverentsist võttis Peterburi delegaat osa otsustava hääleōigusega ainult kultuurilis-hariduslikes küsimustes.

Otsust töölisajakirjanduse kohta ei avaldatud konspiratiivseil kaalutlustel. Sandarmeeria materjalides räägitakse, et võeti vastu otsus ajalehe „Töö Kiir" üleviimiseks Narvast Tallinna 1914. aasta augustiks ${ }^{65}$. Resolutsioonis käesoleva momendi kohta rõhutati 1914. aasta sügisel ettenähtud ülevenemaalise streigi energilise ettevalmistamise vajadust.

Konverents tervitas ülevenemaalise parteikongressi kokkukutsumist ning määras kindlaks oma esindaja valimise korra. Otsustati valida delegaat kogu Eesti parteiorganisatsiooni poolt; kui see osutub võimatuks, siis võib delegaadi valida partei Eesti komitee või äärmisel juhtumil ka Tallinna komitee.

Konverents tervitas VSDTP duumafraktsiooni, soovis talle edu ning avaldas lootust, et Malinovski reeturlik pagemine ei nõrgenda fraktsiooni, vaid liidab töölisi veelgi tihedamalt fraktsiooni ümber ja tugevdab teda.

VSDTP ühtsuse küsimuses otsustas konverents, et ühtsus on võimalik ja soovitav vaid nende sotsiaaldemokraatidega, kes tunnistavad õigeks sotsiaaldemokraatide senikehtinud ühinemise vormeli, s. o. tunnistavad bolševistlikku platvormi.

Edasi otsustas konverents valida Eesti parteitöö juhtimiseks Keskkomitee, kuhu kuuluksid Tallinnast 3 esindajat ning Narvast, Tartust ja Peterburist igaühest 1 esindaja, kusjuures Peterburi esindajal oleks otsustav hääl ainult kultuurilis-hariduslikes küsimustes.

Tabamise ohu tõttu tuli konverents katkestada ning jäid läbi vaatamata küsimused partei tegevusest haigekassades, haridusseltsides ja ametiühingutes ${ }^{66}$.

Eesti bolševike 1914.,aasta juunikonverentsil on Eesti bolševistliku organisatsiooni jaoks suur tähtsus. See oli Eesti bolševike esimeseks konverent-

64 Riiklik Ajaloo Keskarhiiv Moskvas, Politseidepartemangu fond (f. 102-oo), sü. 5, 93. osa, lit. Б, a. 1914, 1. 69.

65 Sealsamas.

66 Mingisuguseid konverentsi dokumente pole seni leitud. Aruanne konverentsi kohta avaldati ajalehes „Töö Kiir" nr. 7, 9. juulil 1914. a. See ongi peamiseks allikaks. On selge, et ta ei anna täielikku pilti, sest konspiratiivsetel kaalutlustel ei avaldatud osa materjalidest. 
siks pärast 1905.-1907. a. revolutsiooni lüüasaamist. Konverents kinnitas ja viis lōpule selge piiri tōmbamise bolševike ja likvidaatorite vahele, viis lõpule terava võitluse partei vaenlastega, mida Eesti bolševikud olid pidanud kogu reaktsiooni- ja tõusuperioodi kestel, tegi lõpu kindlusetusele, kokkuleplusele ja kõikumistele ning lõi lōppeks Eesti parteikeskuse.

Seega vabanesid Eesti bolševikud sõja eel oma ebaküpsusest, ideelisest ja organisatsioonilisest nõrkusest ning lõid ühtse bolševistliku organisatsiooni ühtse keskusega, mis töötas partei Keskkomitee ja tema Venemaa büroo juhtimisel ning oli tihedasti seotud partei legaalse keskusega IV Riigiduuma bolševistliku fraktsiooniga ja ajalehega „Pravda”.

Noupidamise ja parteikonverentsi organiseerimine Eestis oli seotud partei kongressi ettevalmistustega, mida sel perioodil pingeliselt tegid Venemaa bolševikud. Piirkondade parteikeskuste loomine ja kohalike parteikonverentside korraldamine oli selle ettevalmistuse tähtsaks elemendiks.

Partei kongressi kokkukutsumise küsimust arutati juba VSDTP Keskkomitee Poronini nõupidamisel parteitöötajatega. Otsustati kongress kokku kutsuda samaaegselt rahvusvahelise kongressiga, mida Internatsionaal valmistas ette 1914. aasta augustiks, ning mõlema kongressi saadikute valimised omavahel kooskõlastada. V. I. Lenin püstitas ülesandeks saavutada seda, et rahvusvahelisel kongressil oleks esindatud tõeline Vene proletariaat ja tema partei.

Organisatsioone, kes tehnilistel või konspiratiivsetel põhjustel ei saanud saata oma delegaate, pidi esindama duumafraktsioon. Kõik saadikud-bolševikud peavad tingimata ilmuma kongressile, ütles Lenin, sest nad on ise töölised ja on Venemaa töölisklassi tõelised esindajad ${ }^{67}$.

Keskkomitee liikmete nõupidamisel 1914. aasta aprillis kavandati kongressi päevakord ja kongressi koosseis, kusjuures Eesti pidi saatma $1-2$ delegaati ${ }^{68}$.

Seoses kongressi ettevalmistusega ja täites oma konverentsi otsuseid, arutasid Tallinna bolševikud suurel põrandaalusel nõupidamisel 28. juunil Risti metsas Tallinna lähedal delegaadi valimist parteikongressile ning otsustasid volitused anda Riigiduuma bolševistlikule fraktsioonile.

Samal nõupidamisel valiti Tallinna poolt kolm esindajat Eesti Keskkomiteesse ${ }^{69}$.

Koosolek otsustas ka korraldada aktiivse agitatsiooni Kastra ajakirja „Kinnituse Küsimused” levitamise vastu tööliste hulgas.

Loonud oma parteikeskuse, tihendasid Eesti bolševikud veelgi oma sidemeid partei Keskkomiteega ja asusid selle juhtimisel töölisklassi revolutsioonilise võitluse etteotsa. Sel ajal tõusis revolutsiooni laine Venemaal üha kõrgemale. Juulis haarasid maad massilised streigid, demonstratsioonid ja miitingud. Peterburis, Bakuus ja Lodzis läks asi juba barrikaadideni. Seoses nende sündmustega andis Tallinna komitee välja ja levitas ööl vastu 10. juulit laialdaselt proklamatsiooni, mis kutsus töölisi üles streigiks ja demonstratsiooniks bolševistliku partei revolutsiooniliste loosungite all ${ }^{70}$.

10. juulil algas grandioosne streik, millest võtsid osa peaaegu kõik Tallinna töölised - ligemale 15000 inimest.

Enne streigi algust toimusid ettevõtetes miitingud, mille järel töölised, lauldes revolutsioonilisi laule, väljusid tehastest. Toimusid miitingud „Wie-

67 А. Бад а ев, Большевики в Государственной думе. Воспоминания, Изд. 8-е, Госполитиздат 1954, стр. 326-327.

68 Sealsamas, lk. 328.

69 Riiklik Ajaloo Keskarhiiv Moskvas, Politseidepartemangu fond (f. 102-oo), sü. 5, 93. osa, lit. Б, a. 1914, lehed $72-73$. - Sealsamas, 7. osakond, nr. 1076, a. 1915, 1. 11.

70 Sealsamas, f. 102, 4. osakond, sü. 88, 2. osa, a. 1914, lehed 59-60. — "Töö Kiir” nr. 8, 12. juulil 1914. a. 
gandi" tehase ees, Viru tänaval ja Merepuiesteel. Politsei ja ratsapolitsei ajas meeleavaldajad laiali. Leidsid aset demonstrantide kokkupõrked politseiga ja arreteerimised ${ }^{71}$.

Sündmused Tallinnas tegid tsaarivõimud niivõrd rahutuks, et Peterburist saadeti Tallinna politseiülemad ${ }^{72}$.

Revolutsiooni tõusu Venemaal katkestas sel ajal alanud esimene imperialistlik maailmasõda.

EKP Keskkomitee juures asuv Partei Ajalco Instituut
Saabus toimetusse

24. V 1955

\title{
БОЛЬШЕВИКИ ЭСТОНИИ ПЕРЕД ПЕРВОЙ МИРОВОЙ ВОЙНОЙ
}

\author{
С. А. ЗАБРОДСКАЯ, \\ кандидат исторических наук
}

Резюме

Накануне первой мировой войны Россия шла навстречу новой революции. Революционный подъем 1912-1914 годов происходил в обстановке экономического подъема.

В Эстонии быстро росла металлообрабатывающая, деревообделочная, химическая и другие отрасли промышленности. Число рабочих на крупных предприятиях (с числом рабочих больше 500 человек) увеличилось с начала столетия до 1913 года вдвое. Усилилось влияние монополистического капитала, в руках которого находилась вся крупная промышленность.

Продолжала усиливаться эксплуатация рабочего класса. Продолжительный рабочий день, сверхурочные работы, низкие заработки, штрафы, отсутствие охраны труда, безработица и т. д. вызывали сильное недовольство рабочих. Қапиталистическая эксплуатация дополнялась в Эстонии национальным гнетом со стороны немецких помещиков и капиталистов и русской буржуазии, а также полицейским произволом царизма. Непосредственным толчком к решительному подъему массового революционного движения явился ленский расстрел.

Годы подъема характеризовались в Эстонии быстрым ростом стачечного движения.

По преуменьшенным официальным данным, в Эстонии в стачках участвовало: в 1911 г. - 352 человека, в 1912 г. - 14132 , в 1913 г. 22109 и в 1914 г. (за полгода до начала войны) -27725 человек.

По всей Эстонии, по более полным данным, число стачечников достигло в 1913 году 28,5 тыс. и в 1914 году за полгода 30 тыс. человек.

В дни годовщин 9 января, 1 мая, 16 октября и др. в Таллине происходили массовые политические стачки, в которых участвовали рабочие всех крупных предприятий. Переплетение же экономической и политической борьбы придавало массовым стачкам особую революционную силу.

Массовые стачки рабочих будили и втягивали в борьбу также крестьянские массы, оказывали революционизирующее влияние на армию и

71 Riiklik Ajaloo Keskarhiiv Moskvas, Politseidepartemangu fond (f. 102), 4. osakond, sü. 88,2 . osa, a. $1914,1,52$. - „Tallinna Teataja” nr. 15310 . juulil ja nr. 154 11. juulil 1914. a.

${ }_{72}$ Sellest teatas Politseidepartemang 11. juulil telegrammis Bakuusse siseminister Džunkovski sōbrale. - Vt. raamat: Цв е тков-Просвеще н ски й, Подъем рабочего движения в России в 1912-14 гг. Госполитиздат, 1939, стр. 106-107. 
флот. В Эстонии батраки и арендаторы отвечали на тяжелый помещичий и кулацкий гнет стихийными выступлениями, поджогами, забастовками.

В революционных выступлёниях на Балтийском флоте участвовали под руководством большевиков и моряки Таллинской базы флота.

Рабочий класс России шел навстречу новой революции под руководством испытанной и закаленной в классовой борьбе Коммунистической партии - партии нового типа, партии ленинизма. Пражская партийная конференция в январе 1912 года очистила партию от оппортунистов, изгнала меньшевиков-ликвидаторов из партии и положила начало окончательному оформлению большевиков в самостоятельную партию.

В годы реакции партийные организации были ослаблены. В Эстонии к началу периода подъема оформленная партийная организация сохранилась только в Таллине, где существовал Таллинский комитет РСДРП.

В течение двух последующих лет оформились и выросли партийные организации также в Нарве, Тарту, Пярну и других городах.

Активное участие в деятельности большевистской организации Эстонии принимали также эстонские большевистские группы в Петербурге и Хельсинки.

К концу периода реакции ликвидаторы были в основном изгнаны из социал-демократических организаций Эстонии. Всю партийную работу на местах вели рабочие-большевики фабрик и заводов. Они руководили стачками, выпускали и распространяли листовки, работали в легальных рабочих организациях. Меньшевики-ликвидаторы к этому времени уже не имели никакой организационной опоры, никаких органов печати и какого-либо серьезного влияния среди рабочих.

С середины 1912 года происходит организация, рост и оформление большевистских организаций вокруг «Правды» и эстонской легальной рабочей газеты «Кийр», которая стала проводником идей «Правды» в Эстонии. «Правда» стояла в центре борьбы за партийность, за воссоздание массовой революционной партии.

Передовые рабочие Эстонии читали и распространяли «Правду», проводили сборы в ее пользу, писали корреспонденции, организовывались вокруг газеты. «Правда» широко освещала положение в Эстонии и борьбу, происходившую здесь. Она поместила за два года около 200 статей и заметок из Эстонии и посвятила Прибалтийскому краю специальный листок.

Влияние «Правдыз среди эстонских рабочих и крестьян распространялось главным образом через эстонскую правдистскую газету «Кийр», ставшую подлинным коллективным организатором, вокруг которого росли и большевизировались социал-демократические организации. Вначале «Кийр» не имел ясной и последовательной платформы, допускал ошибки, проявлял примиренчество к оппортунистам, но постепенно, под влиянием «Правды» и нараставшего революционного подъема, при активной помощи большевиков Петербурга и, в частности, В. Кингисеппа линия газеты была выправлена, она стала подлинно большевистским пропагандистом и агитатором.

Газета «Кийр» отстаивала большевистскую тактику и, в частности, выступила против участия социал-демократов в буржуазной печати, причем она резко столкнулась с членом Таллинского комитета РСДРП Кастра и группой его сторонников. Кастра был членом редакции буржуазно-либеральной газеты Пятса «Таллина Театая» и вел в интересах буржуазии борьбу против рабочей газеты. Объявляя себя большевиком и борцом за партийность, Кастра был на деле замаскированным ликвидатором. Большевики Таллина боролись за очищение своих организаций от скрытых ликвидаторов, за создание подлинно большевист- 
ского Таллинского комитета. Эта задача была выполнена к весне 1914 года при активной помощи со стороны ЦҚ РСДРП, большевистской фракции Государственной думы и «Правды».

В 1912 - 1914 годах большевистские организации Эстонии достигли серьезных успехов в деятельности подпольных организаций и расширении связей с массами путем использования всех легальных возможностей. Они вели серьезную идейную борьбу, в частности против эстонского буржуазного национализма.

Число сторонников партии неуклонно росло, что наглядно показывает рост сборов на «Кийр», а также на «Правду». Организуясь вокруг «Кийр», большевики добивались создания общеэстонского партийного центра. Этого требовали и решения Краковского и Поронинского партийных совещаний. Важным шагом в этом направлении было совещание пайщиков «Рахва Сына» в Петербурге $6-8$ октября под руководством В. Кингисеппа.

Раскол социал-демократической фракции Государственной думы в октябре 1913 года поставил ребром вопрос перед каждой организацией и членом партии - за шестерку (большевиков) или семерку (меньшевиков), за партию нового типа, непримиримую к оппортунистам, или за соглашательство с ними, т. е. раскол способствовал изжитию примиренчества, в том числе и в Эстонии. Большинство эстонских рабочих социал-демократов высказывалось за шестерку,

ЦК РСДРП помог эстонским большевикам окончательно порвать с оппортунистами. В. И. Ленин дал после Поронинского совещания задание большевистскому депутату Г. И. Петровскому помочь партийной организации Эстонии. В то же время и эстонские большевики приняли со второй половины 1913 года меры к установлению связей с ЦК и с большевистской фракцией. В. Кингисепп в переговорах и переписке с фракцией и ЦК поставил от имени редакции «Кийр» вопрос о сотрудничестве фракщии и большевистских русских литераторов в эстонской газете и об установлении над ней контроля ЦҚ РСДРП. Он ознакомил руководящие органы партии с положением в Эстонии, что было очень важно, так как Кастра в своих письмах пытался ввести ЦК в заблуждение.

Выполняя задание ЦК, Петровский приехал 22 марта 1914 года в Таллйн, где под его руководством состоялось совещание социал-демократов-партийцев Әстонии.

Найденные в Поронинском архиве В. И. Ленина резолюции этого совещания показывают, что оно приняло важнейшие решения о признании позиции партии правильной, об одобрении деятельности большевистской шестерки, о необходимости установления более тесных связей с думской фракцией, с «Правдой» и с русскими товарищами, в частности петербургскими.

Совещание признало газету «Кийр» партийным органом. Было принято также специальное решение, в котором совещание осудило поведение Кастра и Таллинского комитета и потребовало роспуска Таллинского комитета и избрания нового. Таким образом, произошел окончательный разрыв эстонских большевиков с оппортунистами - в этом историческое значение совещания.

После совещания думская фракщия признала «Кийр» большевистским органом, а в начале апреля ЦК РСДРП подтвердил это постановление и решил оказать «Кийр» денежную помощь в размере 200 руб. Вслед за тем «Правда» и Ленин с полным основанием назвали эстонскую газету правдистской.

После совещания большевики - рабочие Таллина создали новый 
Таллинский комитет, который вскоре возглавил крупное первомайское выступление и массовые стачки и демонстрации в июле 1914 года.

На основе решения совешания и в связи с подготовкой к съезду партии большевики Эстонии подготовили и провели 15 июня 1914 года первую после поражения революции 1905-1907 гг. общеэстонскую партийную конференцию близ Нарвы. Конференция обсудила доклады с мест, приняла решение по вопросу о рабочей печати, признала необходимой энергичную подготовку к проведению общероссийской всеобщей стачки, приветствовала созыв Всероссийского партийного съезда, приветствовала большевистскую фракцию. По вопросу об единстве партии конференция решила, что единство возможно и желательно лишь с теми социал-демократами, которые признают большевистскую платформу. Конференция решила избрать Центральный Комитет Эстонского Края из трех представителей от Таллина и по одному представителю от Нарвы, Тарту и Петербурга. В связи с угрозой провала, вопросы о деятельности партии в больничных кассах, просветительных обществах и профсоюзах остались на конференции нерассмотренными.

Конференция имела важное значение. Она завершила и закрепила полное размежевание большевиков с врагамн партии и создала краевой партийный центр.

Представители Таллина в ЦК Эстонского Края были избраны 28 июня на большом подпольном собрании в лесу Ристи близ Таллина. Там же обсуждался вопрос об избрании делегата на съезд партии и было решено передать полномочия большевистской фракции думы.

. Таким образом, большевики Эстонии накануне войны освободились от незрелости, идейной и организационной слабости и влияния примиренчества и создали единую большевистскую организацию с единым центром, работавшую под руководством ЦК партии и его русского бюро, тесно связанную с легальными центрами партии - большевистской фракцией думы и газетой «Правда».

Институт истории партии при ЦК КП Эстонии
Поступила в редакцию 24 V 1955 